\title{
TAXATION OF BEVERAGES AND SWEETENED PRODUCTS IN MOROCCO: A MAJOR ACHIEVEMENT AND A MODEL TO FOLLOW IN THE MENA REGION.
}

\author{
Jamal Belkhadir ${ }^{1,2,3}$, Mostafa Brahimi ${ }^{1,3}$, Hassan Aguenaou ${ }^{1,2,3}$, Jaâfar Heikel ${ }^{2,3}$, Hicham El Berri ${ }^{1,3}$, Latifa Belakhal ${ }^{1,4}$, \\ Fatima Gouaima Mazzi ${ }^{1,3}$, Kébira Benabed ${ }^{1}$
}

${ }^{1}$ Moroccan League for the Fight against Diabetes

${ }^{2}$ Moroccan Society of Nutrition, Health and Environment

${ }^{3}$ Moroccan Obesity Task Force

${ }^{4}$ Ministry of Health, Morocco.

\begin{abstract}
The analysis of the various reports of the epidemiological situation of obesity and diabetes in Morocco with in particular the reports of the WHO, the High Commission for Planning of Morocco (HCP) and the report of the American McKinsey Study Bureau in 2014, shows a sharp increase in diabetes, obesity and their morbidity and mortality.

With a Moroccan population of 35 million inhabitants in 2017, the number of people with diabetes (2.5 million), pre-diabetes (2.4 million), obesity (3.6 million), overweight (10 million including $63 \%$ of women and $16 \%$ of children) is alarming. The consequences in terms of morbidity and mortality and direct and indirect health costs through reduced productivity for the economy of Morocco and for society as a whole are very high. Total annual expenditure related to obesity amounts to \$ 2.4 billion, or 3\% of Morocco's GDP.

The causes of this increase in obesity and diabetes are closely linked to profound changes in lifestyle: high-calorie diet rich in fast sugars, reduction in physical activity, etc. This is how it is demonstrated that too much consumption of sugary drinks is harmful to weight maintenance, metabolic balance and cardiovascular health. Conversely in many experiments around the world, the number of people with overweight and a risk of diabetes decreases significantly when the reduction of refined sugars is carried out by several preventive measures including increasing the tax on sodas, juices and other sugary drinks.

The members of the Working Group who have been working together for several years in Morocco on the "Taxation of sweet products" within the framework of the Moroccan League for the Fight against Diabetes and the Moroccan Society of Nutrition, Health and Environment, have carried out multiple actions advocacy and sensitization with the government, the ministry of health, the parliament, the university, civil society and the media.

The soda tax was finally adopted by the Moroccan Parliament in the 2019 finance bill. A first in the Middle East and North Africa region. In December 2019, a new acquisition was made during the discussion of the Finance Law Project (FLP) 2020 by the introduction of a progressive Internal Consumption Tax (ICT) on sugary drinks in proportion to their sugar concentration. The aim is to encourage manufacturers to reduce the sugar content of sugary drinks and energy drinks to avoid over-taxation. On the other hand, the support recently given in 2020 by the National Council of Human Rights of Morocco to this tax constitutes a very large acquisition, with a new institutional and socio-cultural dimension of human rights for the preservation health in Morocco. Members of the working group will continue their efforts to extend this tax to all products containing a significant amount of sugar. The same is true for other toxic products such as salt, fat and tobacco.
\end{abstract}

Key Words: Obesity - Diabetes - Tax soda - Prevention - Morocco.

Corresponding Author:

Prof. Jamal Belkhadir,

International Diabetes Federation MENA Regional Chair.

E-mail: jamalbelkhadir@idf.org

Address: BP 766, Rabat - Chellah. Morocco

Copyright (C) 2012- 2020 Prof. J. Belkhadir. This is an open access article published under Creative Commons Attribution Non Commercial- No Derives 4.0 International Public License (CC BY-NC-ND). This license allows others to download the articles and share them with others as long as they credit you, but they can't change them in any way or use them commercially.

doi: $10.46327 /$ msrjg.1.000000000000161

*****Published in June 02, 2020.

doi url: https://doi.org/10.46327/msrjg.1.000000000000161

\section{INTRODUCTION}

Recent studies have shown that consuming too much sugary drinks is harmful to weight maintenance, metabolic balance and cardiovascular health [1-3]. Consumed regularly, sugary drinks, providing about $15 \%$ of the day's calorie intake, are a major contributor to the obesity epidemic $[4,5]$. The same is true of the "unacceptable" sugar levels in fruit 
juices, milk products and energy drink smoothies marketed and intended for children and young adolescents [6,7].

It is important to remember that the high consumption of sodas in the world is explained by the composition of these drinks. Rich in sugars, soft drinks and energy drinks do not provide any micronutrients (vitamins, minerals, trace elements, essential fatty acids, amino acids) essential for the proper functioning of our body. On the contrary, they only provide amounts of sugar that are far too high for our daily needs. Indeed, in a $1 / 2$ liter bottle of sweet drink, there is at least 12 teaspoons of sugar, which is quite alarming, because it represents at least 230 Kcalories. In addition, sodas and sugary products are harmful to health and responsible for a long list of pathologies that should be highlighted:

- Diabetes

- Overweight and obesity

- High blood pressure and cardiovascular disease

- Dental caries

- The development of cancers

- Hepatic steatosis

- $\quad$ Aging of cells

- Drop

- Osteoporosis

- Respiratory disorders

- The Depression

Insomnia

- Alzheimer's disease

- Dependence and addiction....

Large studies of primary prevention against diabetes have demonstrated the importance of general lifestyle measures: healthy diet, regular physical activity, tobacco control, etc.) [8]. In addition, the fight against obesity and diabetes goes through the fight against sugar. By reducing the amount of carbohydrates in sodas, juices and other sugary drinks, the number of people who are overweight and at risk of diabetes is significantly reduced. This objective is achieved with the application of taxes allowing a gradual reduction of up to $40 \%$ in the amount of free sugars in these products over a period of five years $[9,10]$.

\section{WHY A TAX ON SUGARY DRINKS IN MOROCCO?}

The Moroccan League for the Fight against Diabetes (LMLCD) and the Moroccan Society of Nutrition, Health and Environment (SMNSE) and with the support of parliamentarians, experts from the Ministry of Health and researchers specializing in Nutrition and Health have analyzed the Epidemiological situation of Obesity and Diabetes in Morocco with in particular the reports of the WHO, the High Commission for Planning of Morocco (HCP), the report of the American Bureau of Study McKinsey in 2014 and the stepwise survey of the Ministry of Health 2017-2018 [11].

Despite all the efforts made by the Kingdom of Morocco, which has 35 million inhabitants, the epidemic of diabetes
(2.5 million), pre-diabetes (2.4 million), 53\% of Moroccans are overweight [obesity in 3.6 million and overweight in 10 million including $63 \%$ of women and $16 \%$ of children in 2017 ], this scourge is in continuous and regular progression. $80 \%$ of deaths in Morocco are attributable to NCDs of which $12 \%$ represent premature mortality [12].

Indeed, the consequences in terms of morbidity and mortality and direct and indirect health costs through reduced productivity for the economy of Morocco and for all of society are very high. Total annual expenditure amounts to 2.4 billion dollars, or $3 \%$ of Moroccan GDP. At the level of health insurance funds, the 2018 annual global report shows that $3,2 \%$ of the population who have recourse to care related to long-term illnesses (ALD) consumes $51,5 \%$ of total expenditure, of which $73.1 \%$ spending are earmarked for the following four diseases: diabetes $(10,4 \%)$, high blood pressure $(10,7 \%)$, chronic kidney disease $(27,4 \%)$ and cancer $(23,4 \%)$ [13].

Based on scientific evidence, WHO reports and successful experiences in many countries (Mexico, France, United Kingdom, Finland, Sweden, Hungary, South Africa, Chile, Brunei, Thailand....), the taxation of drinks and sugary products appears as an important measure in the multidimensional strategy for the fight against the diseases of Nutrition, Obesity and Diabetes [14-16].

In 2016, researchers from the City University of London and the University of North Carolina looked at the consequences of this measure in the countries that have implemented it, compared to other countries where it is not the case. From a list of 54 countries, they concluded that the consumption of sugary drinks is increasing all over the world except in countries that have introduced the soda tax. These results can also be extrapolated to other products containing excess sugar [17].

\section{APPROACH}

The Moroccan League for the Fight against Diabetes and the Moroccan Society of Nutrition, Health and Environment, which have been working together for several years in Morocco on the "Tax on beverages and sweetened products", held several working meetings and carried out awareness-raising actions and advocacy with public authorities, parliament, medical / health professionals and academia, media and civil society.

Among the actions carried out at the scientific, social and media level, are:

- the $5^{\text {th }}$ International Conference on Diabetes and Nutrition "Diabetes Morocco 2016" in Rabat on May $13^{\text {th }}$ and $14^{\text {th }}, 2016$;

- the $6^{\text {th }}$ International Conference on Diabetes and Nutrition "Diabetes Morocco 2017" in Rabat on July $7^{\text {th }}$ and $8^{\text {th }}, 2017$;

- the celebration of World Diabetes Day in Dakhla on November $11^{\text {th }}, 12^{\text {th }}$ and $13^{\text {th }}, 2016$, and at the Mohammed VI International University of Benguerir, on November $10^{\text {th }}, 11^{\text {th }}$ and $12^{\text {th }}, 2017$; 
- "Healthy Life" Days in Rabat at the CNRST on December $9^{\text {th }}$ and $10^{\text {th }}, 2017$;

- the $7^{\text {th }}$ International Colloquium on Diabetes and Nutrition "Diabetes Morocco 2018" in Rabat on July $6^{\text {th }}, 7^{\text {th }}$ and $8^{\text {th }}, 2018$;

- meetings with the various parliamentary groups in November 2017, November 2018 and November 2019;

- The national survey on risk factors for NCDs carried out by the Ministry of Health in 2017 - 2018 among people over 18 years old;

- $\quad$ World Diabetes Day in Kenitra on November $9^{\text {th }}$ and $10^{\text {th }}, 2018$;

- $\quad$ the $8^{\text {th }}$ National Symposium on Diabetes and Nutrition "Diabetes Morocco 2019" in Kenitra on July $5^{\text {th }}$ and $6^{\text {th }}$, 2019;

- World Diabetes Day in Laâyoune, November $8^{\text {th }}$ and $9^{\text {th }}, 2019$.

After the efforts made in November 2017 on the occasion of the 2018 Finance Law Project (FLP), the soda tax was adopted by the Moroccan Parliament in the 2019 FLP. A first in the Middle Region East and North Africa. Indeed, the Internal Consumption Tax (ICT) has been increased substantially by $50 \%$ for sugary drinks and even more for energy drinks [18].

In December 2019, a new acquisition was made during the discussion of the PLF 2020 by the introduction of a progressive ICT on sugary drinks in proportion to their sugar concentration. The aim is to encourage manufacturers to reduce the sugar content of sugary drinks and energy drinks to avoid over-taxation.

In addition, a study day on the same theme, devoted to cookies - dairy products - chocolates - etc. is planned for the year 2020 bringing together the various partners: government, parliament, WHO, agri-food industry, university, civil society (consumer protection) and media.

While congratulating all of our parliamentarians for this historic decision and the Moroccan government for having consolidated this progressive ICT on sugary drinks in proportion to their sugar content in the 2020 FLP, the working group underlines the importance of the continuation advocacy and awareness-raising efforts among health professionals and the general public.

Moreover, all these efforts have just been corroborated by the adoption, under the chairmanship of the Head of Government of Morocco, of a National Charter for the prevention and control of Non-Communicable Diseases, which affirms the Government's commitment. , parliamentarians and civil society, on April 8, 2019. On this occasion, WHO presented Morocco with a trophy saluting our country's efforts in this area.

For the future, the working group wishes to extend this tax on sweetened drinks to all products containing a significant amount of sugar (cookies, confectionery, sweet dairy products, chocolates, candies, etc.) and to pay them into the budgets allocated to health, sport and a healthy lifestyle. This behavioral tax, mentioned in the National
Multisectoral Strategy for the Prevention and Control of Non-Communicable Diseases 2019 - 2029 [19], has a dual objective:

- Encourage the agri-food industry to lower the sugar levels in their products;

- Guide citizens, in particular children, parents and poor populations, to consume less sweet, less taxed, cheaper and healthier products.

Finally, it is important to underline that the National Council of Human Rights in Morocco, specified in its 2019 report, published in March 2020 [20], the importance of prevention in the health system in order to preserve one of the most fundamental human rights which is health and insisted in its Memorandum presented to the Special Commission on the Development Model (CSMD) on the role of the taxation of sweet products [21]. The latter is a very effective tool in the fight against obesity and Noncommunicable Diseases. This constitutes a very large acquisition, with a new institutional and socio-cultural dimension of human rights for the preservation of health in Morocco.

\section{CONCLUSION}

The members of the Working Group who have been working together for several years in Morocco on the "Taxation of sweetened products" within the framework of the Moroccan League for the Fight against Diabetes and the Moroccan Society of Nutrition, Health and Environment, welcome the results obtained in 2018, 2019 and 2020.

They underline that the support recently given in 2020 by the National Council of Human Rights of Morocco to this tax constitutes a very important acquisition, with a new institutional and socio-cultural dimension of human rights for the preservation of health in Morocco.

They promise to continue advocacy and awareness-raising work in parliament, government, media and civil society for the extension of this tax to all products containing a significant amount of sugar. The same is true for other toxic products such as salt, fat and tobacco. 


\section{REFERENCES}

1. Josefin E Löfvenborg, et al. Sweetened beverage intake and risk of latent autoimmune diabetes in adults (LADA) and type 2 diabetes. European Journal of Endocrinology (2016) 175, 605-614.

2. Matthew P. Pase. Sugar-and Artificially Sweetened Beverages and the Risks of Incident Stroke and Dementia. Stroke. 2017;48:1139-1146. DOI: 10.1161/STROKEAHA.116.016027.

3. Kmietowicz Z. Type 2 diabetes: sweetened drinks pose greater risk than other sugary foods. BMJ $2018 ; 363: \mathrm{k} 4943$.

4. Iffat R., et al. The relationship between sweetened beverage consumption and risk of heart failure in men. Heart 2015;101:1961-1965. doi:10.1136/heartjnl-2015-307542.

5. Qibin Qi, et al. Sugar-Sweetened Beverages and Genetic Risk of Obesity. N Engl J Med 2012; 367:1387-1396.

6. Jiantao Ma, et al. Sugar-sweetened beverage consumption is associated with change of visceral adipose tissue over 6 years of follow-up. Circulation. 2016;133:370-377.

7. Boulton $\mathrm{J}$, et al. How much sugar is hidden in drinks marketed to children? A survey of fruit juices, juice drinks and smoothies. BMJ Open 2016;6:e010330. doi:10.1136/bmjopen-2015-010330.

8. J. Belkhadir, Diabetes and the Prospect of a National and Global Disaster. Journal of Medical and Surgical Research JMSR- 2015; I (3): 77- 78.

9. Ma Y, He FJ, Yin Y, Hashem KM, MacGregor GA. Gradual reduction of sugar in soft drinks without substitution as a strategy to reduce overweight, obesity, and type 2 diabetes: a modelling study. Lancet Diabetes Endocrinol 2016; 4: 10514.

10. Schilinger D. Guidelines to limit added sugar intake : jenk science or jenk food ? Editorial. Ann Intern Med ; 166 : 305306. 02/2017.

11. Enquête Nationale sur les facteurs de risque communs des Maladies Non transmissibles 2017-2018. https://www.sante.gov.ma/Publications/Etudes_enquete/Pag es/default.aspx

12. WHO 2016 Risk of premature mortality due to NCDs : https://www.who.int $/ \mathrm{nmh} /$ countries/mar_en.pdf?ua=1

13. Rapport annuel Global de l'AMO, ANAM, 2018. http://www.anam.ma/wpcontent/uploads/2015/06/RAG2018-VF.pdf (accessed Sept 26, 2020).

14. Choo VL, et al. Food sources of fructose-containing sugars and glycaemic control: systematic review and meta-analysis of controlled intervention studies. BMJ. 2018 Nov 21;363:k4644.

15. Diana Quirmbach, et al. Effect of increasing the price of sugar-sweetened beverages on alcoholic beverage purchases: an economic analysis of sales data. J Epidemiol Community Health 2018;72:324-330. doi:10.1136/jech-2017-20979

16. Duffey KJ, Gordon-Larsen P, Shikany JM, Guilkey D, Jacobs DR Jr, Popkin BM. Food Price and Diet and Health Outcomes: 20 Years of the CARDIA Study. Arch Intern Med 2010; 170: 420.

17. Yuan Ma, et al. Gradual reduction of sugar in soft drinks without substitution as a strategy to reduce overweight, obesity, and type 2 diabetes: a modelling study. Lancet Diabetes Endocrinol 2016; 4:105-14. January 6, 2016 http://dx.doi.org/10.1016/ S2213-8587(15)00477-5.

18. Crétois J. Maroc : en taxant davantage les boissons sucrées, le royaume veut guérir de son diabète - Jeune Afrique. 2018; published online Nov 14.

https://www.jeuneafrique.com/664200/societe/maroc-entaxant-davantage-les-boissons-sucrees-le-royaume-veutguerir-de-son-diabete/ (accessed Sept 26, 2020).

19. Stratégie Nationale Multisectorielle de Prévention et de Contrôle des Maladies Non Transmissibles 2019- 2029, Ministère de la Santé https://webcache.googleusercontent.com/search?q=cache:M Ydflt6721UJ:https://www.sante.gov.ma/Documents/2019/02 /Plan\%2520Strate\%25CC\%2581gique.pdf $+\& \mathrm{~cd}=1 \& \mathrm{hl}=\mathrm{fr} \& \mathrm{c}$ $\mathrm{t}=\mathrm{clnk} \& \mathrm{gl}=\mathrm{ma}$

20. Rapport du Conseil National des Droits de l'Homme 2019. Mars $2020 \quad$ (version arabe) https://cndh.ma/sites/default/files/ltqryr_lsnwy_2019.pdf

21. Mémorandum du CNDH sur le nouveau modèle de développement intitulé « l'effectivité des droits et liberté au Maroc. Pour un nouveau contrat social ». diffusé en Aout 2020.http://www.maroc.ma/fr/actualites/le-cndh-presenteson-memorandum-sur-le-nouveau-modele-dedeveloppement 